\title{
Assessing Causes of Change in the Freshwater Mussels (Bivalvia: Unionidae) in the Black River, Ohio
}

\author{
Mark S. Lyons \\ Cleveland State University \\ Robert A. Krebs \\ Cleveland State University, r.krebs@csuohio.edu \\ Jeremy P. Holt \\ Cleveland State University \\ Louie J. Rundo \\ Cleveland State University
}

W. Zawiski

Ohio EPA

Follow this and additional works at: https://engagedscholarship.csuohio.edu/scibges_facpub

Part of the Biodiversity Commons, and the Biology Commons

How does access to this work benefit you? Let us know!

\section{Recommended Citation}

Lyons MS, Krebs RA, Holt JP, Rundo LJ, Zawiski W. 2007. Assessing causes of change in the freshwater mussels (bivalvia: Unionidae) in the black river, ohio. Am Midl Nat 158(1):1-15.

This Article is brought to you for free and open access by the Biological, Geological, and Environmental Sciences Department at EngagedScholarship@CSU. It has been accepted for inclusion in Biological, Geological, and Environmental Faculty Publications by an authorized administrator of EngagedScholarship@CSU. For more information, please contact library.es@csuohio.edu. 


\title{
Assessing Causes of Change in the Freshwater Mussels (Bivalvia: Unionidae) in the Black River, Ohio
}

\author{
MARK S. LYONS, ROBERT A. KREBS, ${ }^{1}$ JEREMY P. HOLT, \\ LOUIE J. RUNDO AND W. ZAWISKI ${ }^{2}$ \\ Department of Biological, Geological, and Environmental Sciences, Cleveland State University, 2121 Euclid Ave., \\ Cleveland Ohio 44115
}

\begin{abstract}
Habitat destruction is believed to be the number one cause of the decline in unionid mussels. Around the world, cities, towns and agriculture alter the structure of watersheds, and the Black River in Ohio may be a typical example. We investigated the diversity and abundance of unionid mussels in this watershed and compared results to urbanization locations, to site-specific appearance of the habitat and to a 1997 fish survey, as host species are another factor important to the distribution of unionid mussels. Although shells were found for 21 species, only 11 of these species were found alive. Seven of the species represented only by shells occurred only in the urbanized lower main stem of the river and less than five shells were found for each. Most of these shells were old and worn. Furthermore, the present assemblage in the main stem varied from shells obtained at a nearby archeological site, and from a voucher set of species obtained at the turn of the 20th Century. Mussel communities higher in the river and those in tributaries were less diverse, but abundance of the species present was higher than in the main stem. A lack of fish hosts may limit mussel diversity, as hosts for several species present in the main stem do not reside higher in the watershed. Overall, mussel assemblages in the Black River appear typical for the region with relatively abundant, but low diversity communities upstream of the cities that line Lake Erie's coast and diverse, but small and potentially threatened, populations in the urban regions.
\end{abstract}

\section{INTRODUCTION}

Urbanization and other changes to stream environments present a variety of stresses to a riverine ecosystem that may be apparent in studies of faunal communities. Freshwater mussels (Mollusca: Bivalvia: Unionidae) inhabit nearly every freshwater environment, from nutrient poor arctic rivers to highly eutrophic streams and lakes, and even temporary flood plains (Bauer and Wachtler, 2001). Nonetheless, a change in the conditions of a particular stream will directly impact the mussels present today (Hughes and Parmalee, 1999; Hardison and Layzer, 2001) or change the communities of the fish hosts mussels require to reproduce (McClelland et al., 2006). For example, the modification of free flowing rivers with dams creates a lacustrine type environment, which dramatically impacts the ecology and, therefore, the fauna and flora of these areas (Vaughn, 1997), and it separates upstream and downstream populations (Watters, 1996). Although unionid mussels will be only one of the impacted groups of species, they are strong ecological indicators (Lawler et al., 2003) and they contribute to water quality by turning over stream sediments, filtering particulate matter and storing toxicants in their tissues (James, 1987; Strayer et al., 1994; Vaughn and HakenKamp, 2001).

Two of the biggest predictors of mussel diversity are the fish species present (Vaughn and Taylor, 2000; Dillon, 2000) and water cleanliness (Metcalfe-Smith et al., 1998, 2000). Unionid mussels are parasitic in their larval stages of life when they attach to a fish host as

\footnotetext{
${ }^{1}$ Corresponding author: e-mail: r.krebs@csuohio.edu; Telephone: 216-523-7553; FAX: 216-687-6972

${ }^{2}$ Ohio EPA, 2110 East Aurora Road, Twinsburg, 44087
} 
glochidia. The link to fish likely controls their migration, as they likely travel farther during this usually brief period than can the adult mussel during its entire life (Seshaiya, 1969). Furthermore, availability of hosts vary considerably among mussel species and mussel reproduction is often specialized to particular groups of fishes (Haag and Warren, 2000). At one extreme, Potamilus alatus (the pink heelspliter) and Leptodea fragilis (the fragile papershell) infest just one species of fish Aplodinotus grunniens (freshwater drum) (Howard, 1913; McGill et al., 2002), whereas Pyganodon grandis (the giant floater) can infest many species (Watters, 1995). Therefore, the species area relationships for mussels and for fish can be similar and the linear correlation of fish to mussel diversity can be as high as $r=0.96$ (Watters, 1992).

To assess habitat quality we surveyed freshwater mussels in most of the $1,300 \mathrm{~km}^{2}$ of the Black River watershed, Ohio (Fig. 1). The degree to which urbanization impacts species richness of mussels was explored by scoring for obvious human alterations to the watershed each time mussels were surveyed. The headwaters of the East Branch Black River flow from the town of Lodi, OH, and the West Branch Black River begins east of New London, OH. The faunal communities in both of these upper branches of the river are isolated from the main stem historically by 7-10 m-high waterfalls that occur just before the their confluence to form the main stem. Dams are also present upstream and downstream of both waterfalls, the highest of which is $5 \mathrm{~m}$. Together, these structures prevent any movement of fish or mussels between these reaches of the river, and the numerous low-head dams that form impoundments upstream of the natural waterfalls (at sites 7 and 26, Fig. 1) potentially impact mussel populations locally (Combes and Edds, 2005). In sum, the Black River flows from unfarmed rural areas, past farming communities and golf courses and eventually through the small cities of Elyria and Lorain in northeastern Ohio.

As part of the assessment of the effects of urbanization on the distribution of mussels, we also examined fish diversity to identify whether any mussels were restricted in their distribution by a lack of a host species. Co-occurrence of fish hosts also may contribute to diversity and abundance of unionids (Watters, 1992), as should watershed size (Dillon, 2000), which was tested by predicting increased diversity of mussels for downstream relative to upstream sites.

\section{Methods}

The main stem of the Black River and East Branch Black River were surveyed in the summer of 2005, and the West Branch Black River and several tributaries were surveyed in the summer of 2006. Survey sites were selected based on accessibility from roads that either crossed or approached the river (Krebs and Rundo, 2005). Care was taken to space sites as evenly as possible (Fig. 1), and each site was surveyed for 2 person-hours by wading either upstream or downstream from points of entry. Time spent identifying and recording data was deducted from the time in the water to ensure that the fully allotted period was devoted to surveying. Surveys combined visual and tactile approaches, with the latter especially important in soft substrates where visibility was low. When live individuals were discovered, they were gently pulled up from the substrate, identified and replaced into their original spot. Spent valves/shells were collected as a second means to estimate relative abundance and diversity of species present at each site. All collected material was deposited at Cleveland State University.

To examine site-specific effects of urbanization, we constructed a simple urbanization rating scale to assess the relative effects of human impacts along the watershed. At each site, seven visible factors typically associated with a human presence were recorded and assessed 


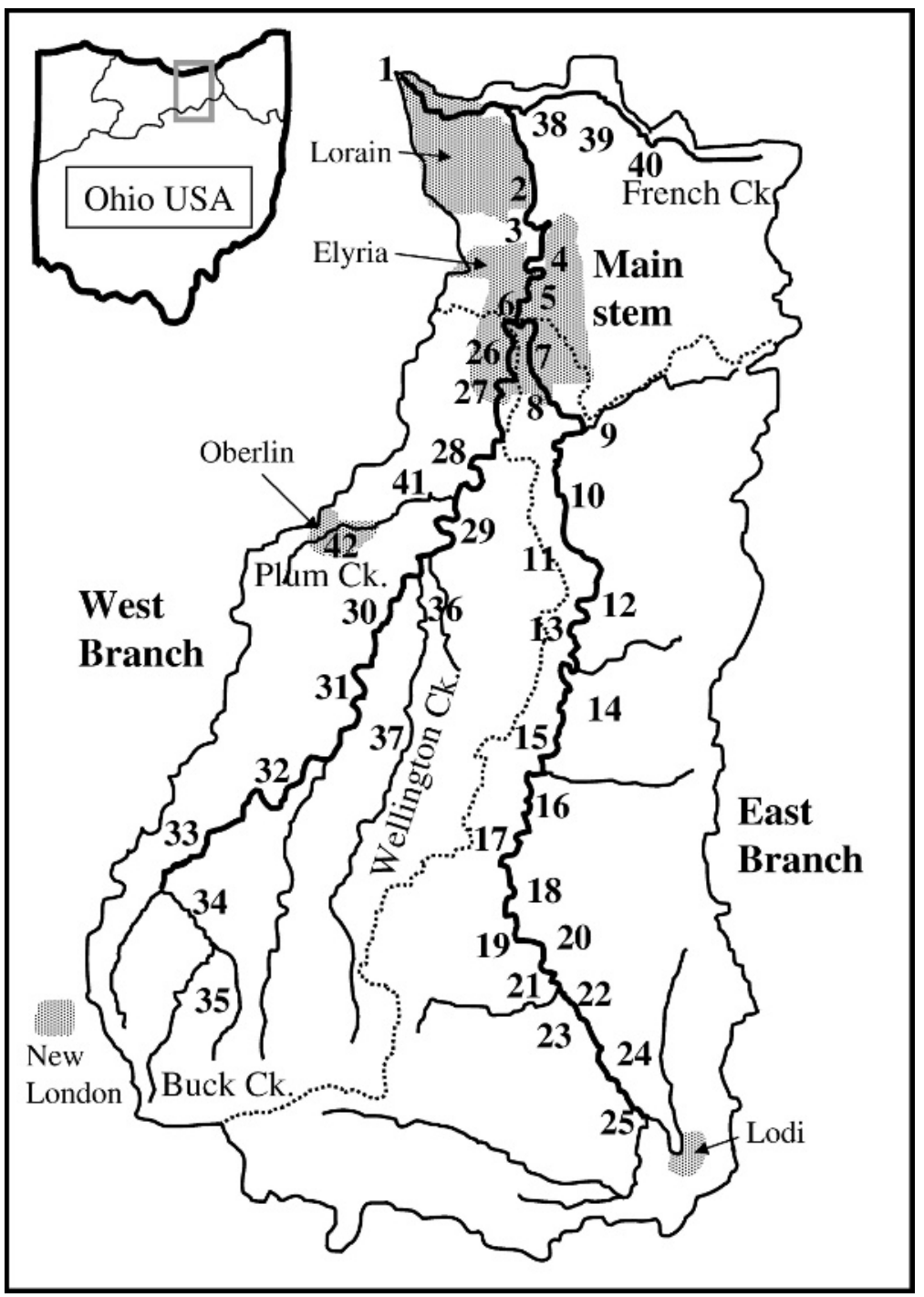

FIG. 1.-Map of the watershed and sampling sites for mussels along the Black River in Ohio: sites 1-6, main stem; sites 7-25, East Branch Black River; sites 26-33, West Branch Black River. Four tributary streams also were surveyed: sites 34 and 35, Buck Creek; sites 36 and 37, Wellington Creek; sites 38-40, French Creek; and sites 41 and 42, Plum Creek. Shading indicates the urbanized regions within the watershed, notably the cities of Lorain, Elyria and Oberlin, Ohio

on a rating scale from 0 to 3 (Table 1), where a score of zero indicated little to no human effects and a score of three denoted extreme modification of the river: (1) the presence of buildings, (2) presence of roads, (3) depth and condition of the riparian zone, (4) condition of the stream bank, (5) presence of dams or spillways, (6) occurrence of erosion and (7) the quantity of trash in the river. Our measure of urbanization may not apply well to 
TABLE 1.-A relative urbanization rating scale that can be applied along a watershed. Each site was assessed as a sum of the scores across seven indicators, which produced a theoretical range of 0-21

\begin{tabular}{|c|c|c|c|c|}
\hline Urbanization indicator & Score $=0$ & Score $=1$ & Score $=2$ & Score $=3$ \\
\hline $\begin{array}{l}\text { Land use: } \\
\text { buildings }\end{array}$ & none & $\begin{array}{l}\text { houses/farming } \\
\text { but not on riparian }\end{array}$ & $\begin{array}{l}\text { housing/farming } \\
\text { near river }\end{array}$ & $\begin{array}{l}\text { high density } \\
\text { urbanization }\end{array}$ \\
\hline Land use: roads & $\begin{array}{l}\text { no contact } \\
\text { with river }\end{array}$ & $\begin{array}{l}\text { minimal } \\
\text { contact/small bridge }\end{array}$ & road along river & $\begin{array}{l}\text { high density of } \\
\text { roadways }\end{array}$ \\
\hline $\begin{array}{l}\text { Riparian zone } \\
\text { condition }\end{array}$ & lush & moderate & $\begin{array}{l}\text { thin condition/ } \\
\text { developed }\end{array}$ & little to none \\
\hline $\begin{array}{l}\text { River bank } \\
\text { modification }\end{array}$ & none & $\begin{array}{l}\text { sparse concrete } \\
\text { rip rap }\end{array}$ & $\begin{array}{l}\text { moderate bank } \\
\text { coverage }\end{array}$ & $\begin{array}{l}\text { majority of bank } \\
\text { covered }\end{array}$ \\
\hline Dam/spillway & none present & $\begin{array}{l}\text { A dam close } \\
\text { but not in site }\end{array}$ & spillway in site & $\begin{array}{l}\text { dam in site } \\
\quad(\geq 2 \mathrm{~m} \text { high })\end{array}$ \\
\hline Erosion & slight & moderate & high & severe \\
\hline Human Trash & insignificant & sparse debris & scattered debris & $\begin{array}{l}\text { concentrated } \\
\text { debris }\end{array}$ \\
\hline
\end{tabular}

differentiate among watersheds because scoring is largely qualitative across sites rather than a discrete measurement, but it is easily applied to describe relative site-specific changes along the length of a river.

The Ohio EPA (1999) surveyed fishes in the Black River several years prior to the present mussel survey. Along $25 \mathrm{~km}$ of the main stem of the Black River, fish samples were collected at 13 sites; eight collections were made along $60 \mathrm{~km}$ of the East Branch Black River and the West Branch Black River was sampled only at one site, $2 \mathrm{~km}$ above where the branches converge to form the main stem (corresponding to our site 27). Sampling techniques followed those described in Ohio EPA's field sampling methodology (Ohio EPA, 1989). Fish collection methods utilized pulsed direct current electrofishing. Fish were collected, identified, counted and weighed before release. Suitability of fish as hosts for specific mussel species is described by the Ohio State University Museum of Biological Diversity website, http://www.biosci.ohio-state.edu/ molluscs/OSUM2/. Most unionid mussels require a fish or alternate host (sometimes an amphibian) to reproduce with the possible exception of Strophitus undulatas (Mackie, 1984) and Utterbackia imbecillis, two species in the subfamily Anodontinae.

\section{RESUlts}

MUSSEL SPECIES PRESENT

We identified 21 species of unionid mussels in the Black River watershed (Fig. 1) based on the presence of shells (Table 2), but of these, only individuals of 11 species were found alive (Fig. 2). A total of 2920 shells and 671 live specimens were recorded. In the short main stem formed from the convergence of the East Branch Black River (EBBR) and West Branch Black River (WBBR), shells of 16 species were recorded, but live individuals were found for just five (Fig. 2): Lampsilis radiata luteola, Lasmigona complanata and L. compressa, which all occurred throughout the river, and two species found only in the main stem, Potamilis alatus and Leptodea fragilis. A sixth species, S. undulatus, occurred alive in French Creek, the one tributary of the main stem large enough to support mussels. Of the 10 species for which we found only shells in the Black River watershed, eight of these records derived from this 
TABLE 2.-The number of shells of unionid mussels collected from the Black River, Ohio, separated by stream sections: the main stem of the Black River, East Branch Black River, West Branch Black River and selected tributary streams. No shells were found in Plum Creek

\begin{tabular}{lcccccc}
\hline \hline \multicolumn{1}{c}{ Species } & $\begin{array}{c}\text { Main stem Black } \\
\text { River }\end{array}$ & $\begin{array}{c}\text { East branch } \\
\text { Black River }\end{array}$ & $\begin{array}{c}\text { West branch } \\
\text { Black River }\end{array}$ & $\begin{array}{c}\text { French } \\
\text { creek }\end{array}$ & $\begin{array}{c}\text { Wellington } \\
\text { creek }\end{array}$ & $\begin{array}{c}\text { Buck } \\
\text { creek }\end{array}$ \\
\hline Actinonaias ligamentina & 2 & 0 & 0 & 0 & 0 & 0 \\
Alasmidonta viridis & 0 & 20 & 0 & 0 & 0 & 0 \\
Alasmidonta marginata & 0 & 11 & 0 & 0 & 0 & 0 \\
Amblema plicata & 23 & 0 & 0 & 0 & 0 & 0 \\
Anodontoides ferussacianus & 0 & 9 & 3 & 3 & 3 & 4 \\
Elliptio dilatata & 4 & 0 & 1 & 0 & 0 & 0 \\
Fusconaia flava & 0 & 1026 & 0 & 3 & 0 & 0 \\
Lampsilis cardium & 4 & 0 & 0 & 0 & 0 & 0 \\
Lampsilis radiata luteola & 7 & 624 & 84 & 3 & 8 & 57 \\
Lasmigona complanata & 35 & 181 & 70 & 5 & 0 & 0 \\
Lasmigona compressa & 0 & 29 & 10 & 2 & 0 & 0 \\
Lasmigona costata & 4 & 0 & 0 & 0 & 0 & 0 \\
Leptodea fragilis & 43 & 0 & 0 & 0 & 0 & 0 \\
Obovaria subrotunda & 1 & 0 & 0 & 0 & 0 & 0 \\
Potamilus alatus & 26 & 0 & 0 & 0 & 0 & 0 \\
Ptychobranchus fasciolaris & 1 & 0 & 0 & 0 & 0 & 0 \\
Pyganodon grandis & 2 & 346 & 60 & 0 & 22 & 7 \\
Strophitus undulatus & 1 & 36 & 5 & 3 & 5 & 6 \\
Truncilla truncata & 1 & 0 & 0 & 0 & 0 & 0 \\
Utterbackia imbecillis & 1 & 0 & 0 & 0 & 0 & 0 \\
Villosa iris novi-eboraci & 0 & 119 & 0 & 0 & 0 & 0 \\
Total shells & 155 & 2401 & 233 & 19 & 38 & 74 \\
\hline
\end{tabular}

survey region, and, with the exception of Amblema plicata, the number of shells found for each of these species was four or less.

In contrast to the 16 species in the main stem, only 10 species were found in the East Branch Black River and seven species in the West Branch Black River (Table 2). Eight of the EBBR and all seven of the WBBR species were found as live specimens. Fusconaia flava was easily the most common species in the river, and its abundance as well as that for mussels generally, peaked in the middle reaches of the EBBR; just three worn valves of $F$. flava appeared in shell collections from the two upper sites of French Creek and none in the WBBR. Villosa iris novi-eboraci was a second species whose distribution was limited to the EBBR, and it was found only between sites 9-15 (Fig. 1). Likewise, the two species identified from shells only in the EBBR, Alasmidonta marginata (11 shells in sites 8 and 9) and A. viridis (20 shells between sites 19 and 25), appeared to possess restricted distributions. Of the other six species present, Anodontoides ferussacianus, Lampsilis radiata luteola, Lasmigona complanata, L. compressa, Pyganodon grandis and Strophitus undulatus, each was found alive in both the EBBR and WBBR. No species was restricted just to the WBBR, although the only live specimen of Elliptio dilatata was found there.

Success in finding individuals alive may in part reflect relative abundance, as the 11 species found alive generally represented the species found most often as shells (comparing Fig. 2, Table 3). Of species identified only from shells in the Black River, more Amblema plicata $(\mathrm{n}=23$ shells, some very fresh) were observed than any of the other nine species, which in numerical order were Alasmidonta viridis $(\mathrm{n}=20)$, Alasmidonta marginata $(\mathrm{n}=11)$, 


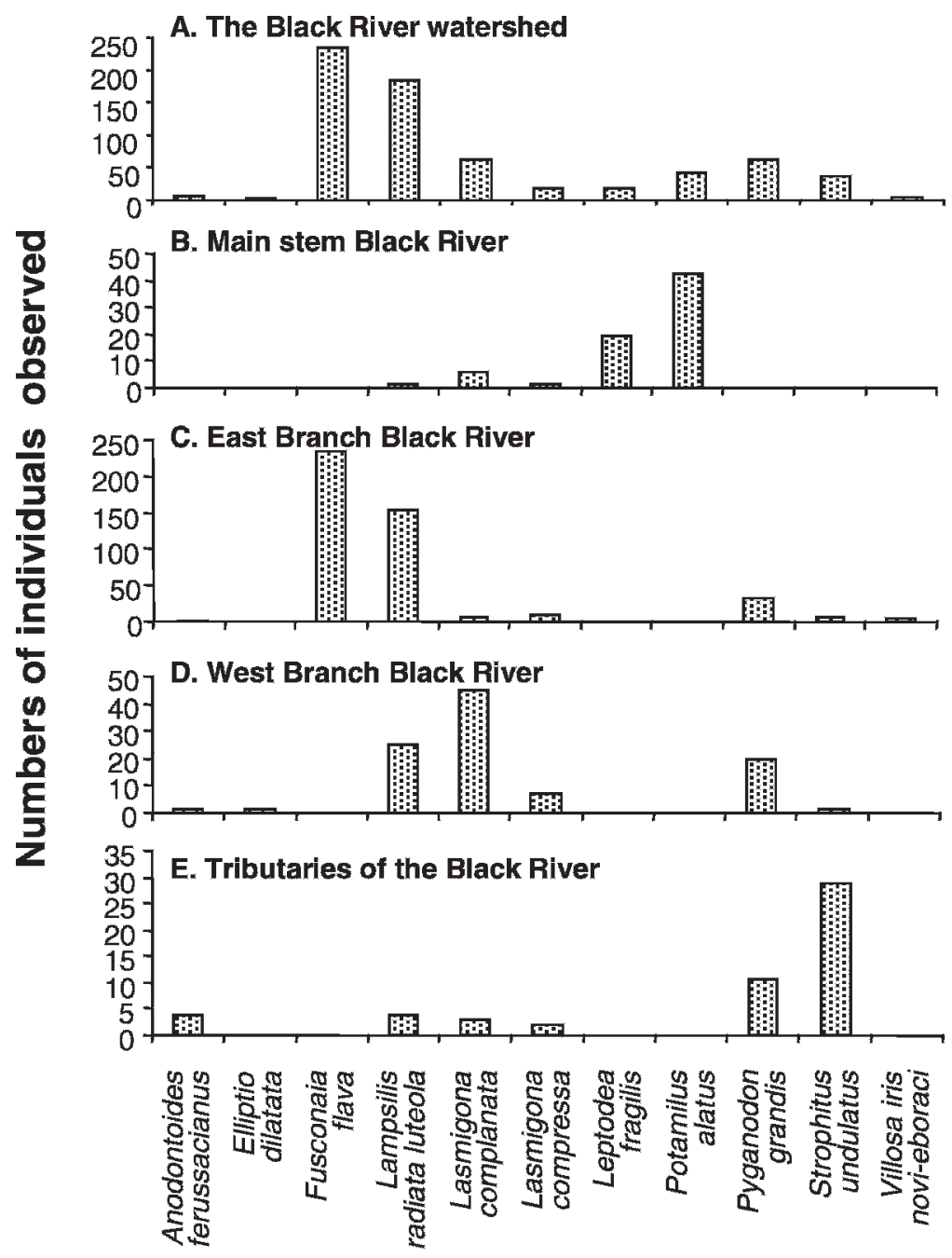

\section{Species found living in the Black River}

Fig. 2.-The number of live unionid mussels observed in the Black River, Ohio, separated by stream sections within (A) the entire watershed, (B) the main stem of the Black River, (C) East Branch Black River, (D) West Branch Black River, (E) tributary streams combined

Lampsilis cardium $(\mathrm{n}=4)$, Lasmigona costata $(\mathrm{n}=4)$, Actinonaias ligamentina carinata $(\mathrm{n}=4)$, and with only one specimen each, Obovaria subrotunda, Ptychobranchus fasciolaris, Truncilla truncata and Utterbackia imbecillis. Because A. viridis grows to only $4 \mathrm{~cm}$, live individuals may have been overlooked due to their small size.

Two upper tributaries of the West Branch Black River were also surveyed, Buck Creek and Wellington Creek, and each contained shells of four species: Anodontoides ferussacianus, Lampsilis radiata luteola, Pyganodon grandis and Strophitus undulatus. In Buck Creek, P. grandis 
and numerous young $S$. undulatus were found alive, while in Wellington Creek, live specimens of Anodontoides ferussacianus, L. radiata luteola and P. grandis were obtained. In a lower tributary, Plum Creek, only a few fragments of $P$. grandis shells were found. The fauna of French Creek, the tributary of the main stem, was more diverse than that of the upper river tributaries. Shells of the same four species as often found in small streams occurred along with the worn Fusconaia flava shells mentioned above, but also live individuals of Lasmigona complanata and L. compressa were found at site 40 (Fig. 1).

\section{EFFECTS OF URBANIZATION}

A regression of human-impact scores (from Table 1) across all sites in the Black River indicated a significant effect of urbanization on species diversity (Fig. 3). Live mussels were always found when the impact score was five or less, indicating low levels of disturbance. High scores, those $>10$, occurred only where the Black River flows through the cities of Elyria and Lorain, and no live mussels were found at any of these five sites. Where sites received scores between five and ten, suggestive of intermediate urbanization effects, they contained live mussels if they possessed protected riparian zones. For example, sites 3-5 encompassed local parks or a golf course in the main stem, while site 8 and site 9 lay within southern suburban Elyria, and site 12 also passed through a golf course (Fig. 1).

\section{IMPACT OF FISH HOSTS}

Table 3 reports fish species present in the main stem Black River, East Branch Black River and West Branch Black River. Fifty-five fish species were found in the watershed although 26 species occurred only in the main stem below the dams. Many of these species may represent transient inhabitants from Lake Erie that entered the river to reproduce. As many as 23 fish species may live throughout the watershed, although only 14 of these 23 were obtained in the brief survey of the WBBR. Just six species possess distributions restricted to the EBBR or WBBR above the high waterfalls that separate them from the main stem.

For almost every site where a live mussel species was present, one or more of that species' hosts were also present (Table 4). The one exception was for Elliptio dilatata in the WBBR. Unionids that had multiple hosts had a greater distribution than those with a single host; Potamilis alatus, Leptodea fragilis and Truncilla truncata only infest freshwater drum, Aplodinotus grunniens, and consequently, these species were restricted to the main stem. Multiple hosts were identified for the five mussel species that live throughout the river: 25 for Pyganodon grandis, 17 for Strophitus undulatus, four for Lasmigona complanata, 11 for L. compressa and 14 for L. r. luteola. However, a multivariate test for the impact of the number of hosts on the range and abundance of mussels showed no relationship other than the correlation between the distribution of freshwater drum and its host-specific fauna (results not shown).

\section{Discussion}

Several factors underlie the distribution and abundance of unionid mussels in the Black River. A presence of 21 unionids and 55 teleost fish suggest good species richness at a watershed level, but of those 21 mussels, at least eight species may be considered at risk locally in the main stem of the Black River. To justify this assertion, a failure to find individuals alive must enable one to conclude that species missing during timed searches are rare. Metcalfe-Smith and DiMaio (2000) tested this assertion specifically by quantifying effects of search length on the likelihood of finding a species. They demonstrated that, while longer search times than we used would improve the chance of detecting rare species, 
TABLE 3.-The number of fishes found in a survey of the Black River, Ohio, conducted by the Ohio Environmental Protection Agency in 1997 (Ohio EPA, 1999, and the mussel species found in the Black River that can use each species as a host, according to Watters (1995) and the Ohio State University Museum of Biological Diversity on-line database http://www.biosci.ohio-state.edu/ molluscs/ OSUM2/. Where associated mussels are indicated as unknown indicates that glochidial relationships to that fish species either have not been found or not studied; where the column is blank indicates that mussel species that can utilize the host are not present in the Black River

\begin{tabular}{|c|c|c|c|c|c|c|}
\hline Species names & Common names & $\begin{array}{l}\text { Main } \\
\text { stem }\end{array}$ & $\begin{array}{c}\text { East } \\
\text { branch }\end{array}$ & $\begin{array}{l}\text { West } \\
\text { branch }\end{array}$ & total & Associated mussels \\
\hline Alosa pseudoharengus & Alewife & 3 & & & 3 & \\
\hline Ictiobus cyrinellus & Bigmouth buffalo & 1 & & & 1 & none known \\
\hline Hybopsis dorsalis & Bigmouth shiner & & & 2 & 2 & none known \\
\hline Pomoxis nigromaculatus & Black crappie & 5 & & & 5 & $1,4,5,6,7,9,11,15,18$ \\
\hline Moxostoma duquesnii & Black redhorse & 1 & & & 1 & none known \\
\hline Rhinichthys atratulus & Blacknose dase & & 1 & 3 & 4 & 15 \\
\hline Percina maculata & Blackside darter & & 22 & & 22 & \\
\hline Lepomis macrochirus & Bluegill sunfish & 229 & 116 & & 345 & $1,4,5,7,8,9,11,15,16,18$ \\
\hline Pimephales notatus & Bluntnose minnow & 1351 & 1183 & 90 & 2624 & $5,9,15,16$ \\
\hline Ameiurus nebulosus & Brown bullhead & 12 & & & 12 & \\
\hline Campostoma anomalum & Central stoneroller & 71 & 736 & 7 & 814 & 1,15 \\
\hline Ictalurus punctatus & Channel catfish & 6 & & & 6 & 16 \\
\hline Cyprinus carpio & Common carp & 321 & 10 & 11 & 342 & $1,10,12,15$ \\
\hline Cyprinus X Carassius & Carp X goldfish & 19 & & & 19 & \\
\hline Luxilus cornutus & Common shiner & & 141 & & 141 & $5,9,15,16$ \\
\hline Semotilus atromaculatus & Creek chub & 4 & 88 & 6 & 98 & $7,11,15,18$ \\
\hline Notropis atherinoides & Emerald shiner & 698 & & & 698 & 11 \\
\hline Etheostoma flabellare & Fantail darter & 1 & 67 & & 68 & 16 \\
\hline Pimephales promelas & Fathead minnow & 1 & 2 & 1 & 4 & 5,16 \\
\hline Aplodinotus grunniens & Freshwater drum & 34 & & & 34 & $13,14,15,17$ \\
\hline Notropis buchanani & Ghost shiner & 1 & & & 1 & none known \\
\hline Dorosoma cepedianum & Gizzard shad & 700 & & & 700 & 11,15 \\
\hline Moxostoma erythrurum & Golden redhorse & 6 & 21 & & 27 & none known \\
\hline Notemigonus crysoleucas & Golden shiner & 264 & & & 264 & 15,18 \\
\hline Carassius auratus & goldfish & 14 & & 33 & 47 & \\
\hline Lepomis sp. & Sunfish hybrids & 8 & 7 & & 15 & none known \\
\hline Lepomis cyanellus & Green sunfish & 45 & 33 & & 78 & $1,4,8,10,11,15,16,18,19$ \\
\hline Etheostoma blennioides & Greenside darter & 569 & 1701 & 161 & 2431 & 19 \\
\hline Etheostoma nigrum & Johnny darter & 12 & 34 & 3 & 49 & $3,15,16$ \\
\hline Micropterus salmoides & Largemouth bass & 247 & 2 & 1 & 250 & $1,5,8,9,10,12,15,16,18,19$ \\
\hline Percina caprodes & Logperch & 72 & & & 72 & \\
\hline Lepisosteus osseus & Longnose gar & 4 & & & 4 & 15 \\
\hline Notropis volucellus & Mimic shiner & 54 & & & 54 & 11 \\
\hline Cottus bairdii & Mottled sculpin & 2 & 70 & 2 & 74 & 3,5 \\
\hline Lepomis gibbosus & $\begin{array}{l}\text { Pumkinseed } \\
\text { sunfish }\end{array}$ & 1035 & & & 1035 & $9,12,15,16,18$ \\
\hline Carpoides cyprinus & Quillback & 3 & & & 3 & none known \\
\hline Etheostoma caeruleum & Rainbow darter & 17 & 142 & & 159 & $15,16,19$ \\
\hline Lythrurus umbratilis & Redfin shiner & & 27 & & 27 & 15 \\
\hline Nocomis micropogon & River chub & 1 & & & 1 & 16 \\
\hline Ambloplites rupestris & Rock bass & 122 & 90 & & 212 & $1,2,4,9,15,16,18,19$ \\
\hline Neogobius melanostomus & Round goby & 1 & & & 1 & \\
\hline Notropis ludibundus & Sand shiner & 147 & 642 & 436 & 1225 & 9,16 \\
\hline
\end{tabular}


TABLE 3.-Continued

\begin{tabular}{|c|c|c|c|c|c|c|}
\hline Species names & Common names & $\begin{array}{l}\text { Main } \\
\text { stem }\end{array}$ & $\begin{array}{c}\text { East } \\
\text { branch }\end{array}$ & $\begin{array}{l}\text { West } \\
\text { branch }\end{array}$ & total & Associated mussels \\
\hline $\begin{array}{l}\text { Moxostoma } \\
\quad \text { macrolepidotum }\end{array}$ & $\begin{array}{l}\text { Shorthead } \\
\text { redhorse }\end{array}$ & 13 & & & 13 & 2 \\
\hline Moxostoma anisurum & Silver redhorse & 2 & & & 2 & none known \\
\hline Notropis buccata & Silverjaw minnow & & 41 & & 41 & 1 \\
\hline Micropterus dolomieu & Smallmouth bass & 143 & 162 & 4 & 309 & $1,8,9,11,16,19$ \\
\hline Ictiobus bubalus & $\begin{array}{l}\text { Smallmouth } \\
\text { buffalo }\end{array}$ & 2 & & & 2 & none known \\
\hline Cyprinella spiloptera & Spotfin shiner & 411 & 193 & 8 & 612 & 16,18 \\
\hline Notropis hudsonius & Spottail shiner & 53 & & & 53 & 5,11 \\
\hline Minytrema melanops & Spotted sucker & 5 & & & 5 & none known \\
\hline Luxilus chrysocephalus & Striped shiner & 484 & 162 & 1 & 647 & $9,15,19$ \\
\hline Morone chrysops & White bass & 31 & & & 31 & $1,4,9,15$ \\
\hline Pomoxis annularis & White crappie & 20 & 1 & & 21 & $1,4,6,7,8,9,10,15,16$ \\
\hline Morone Americana & White perch & 39 & & & 39 & 9 \\
\hline Catostomus commersonii & White sucker & 52 & 50 & 5 & 107 & $2,5,9,15$ \\
\hline Ameiurus natalis & Yellow bullhead & 29 & 61 & & 90 & $11,15,16$ \\
\hline Perca flavescens & Yellow perch & 13 & & & 13 & $1,4,6,8,9,11,15,18,19$ \\
\hline Fish sampled & & 7498 & 5996 & 774 & 14268 & \\
\hline
\end{tabular}

(1) Actinonaias ligamentina, (2) Alasmidonta marginata, (3) Alasmidonta viridis, (4) Amblema plicata, (5) Anodontoides ferussacianus, (6) Elliptio dilatata, (7) Fusconaia flava, (8) Lampsilis cardium, (9) Lampsilis radiata luteola, (10) Lasmigona complanata, (11) Lasmigona compressa, (12) Lasmigona costata, (13) Leptodea fragilis, (14) Potamilis alatus, (15) Pyganodon grandis, (16) Strophitus undulatus, (17) Truncilla truncata, (18) Utterbackia imbecillis, (19) Villosa iris novi-eboraci

estimated to be at abundances of less than five individuals within a site, $2 \mathrm{~h}$ is sufficient to find both common and uncommon species. That no individuals were found for eight main stem species in six site surveys, few fresh shells were found for four of these species, Elliptio dilatata $(\mathrm{n}=4)$, Obovaria subrotunda $(\mathrm{n}=1)$, Truncilla truncata $(\mathrm{n}=1)$ and Utterbackia imbecillis $(\mathrm{n}=1)$, and for four others the shells found were old and worn, A ligamentina $(\mathrm{n}=$ 2), L cardium $(\mathrm{n}=4)$, Ptychobranchus fasciolaris $(\mathrm{n}=1)$ and L. costata $(\mathrm{n}=4)$, suggests that diversity in mussels has declined. Some of these species already may be extirpated locally or possess populations too small to sustain reproduction. This situation is unlikely to change due to a dredged harbor at the mouth of the Black River, the decimation of Lake Erie's unionid fauna by zebra mussels and other anthropogenic changes to the region's landscape (Conroy and Culver, 2004; Bowers et al., 2005).

In contrast to the Black River main stem, the only species of concern in the branch tributaries of the Black River are Alasmodonta marginata in the East Branch Black River (found at sites 8 and 9) and Elliptio dilatata in West Branch Black River (found at sites 28 and 29). Because they were observed only twice in adjacent sites, these two species appear to have a restricted distribution in this stream. All other species besides the small Alasmodonta viridis, for which shells were widely dispersed and not uncommon, were found alive.

Across the watershed, the direct relationship between urbanization and the declining fauna was apparent in analyses of the appearance of survey sites and based on the geographic location of sites within city limits. The negative consequences of urbanization are supported by an examination of historical records for the Black River (Table 5). A Native American shell midden discovered near site 3 (Fig. 1) in the main stem (Tevesz et al., 2002) contained 10 species: Ligumia recta and Toxolasma parous, which were not found in our 


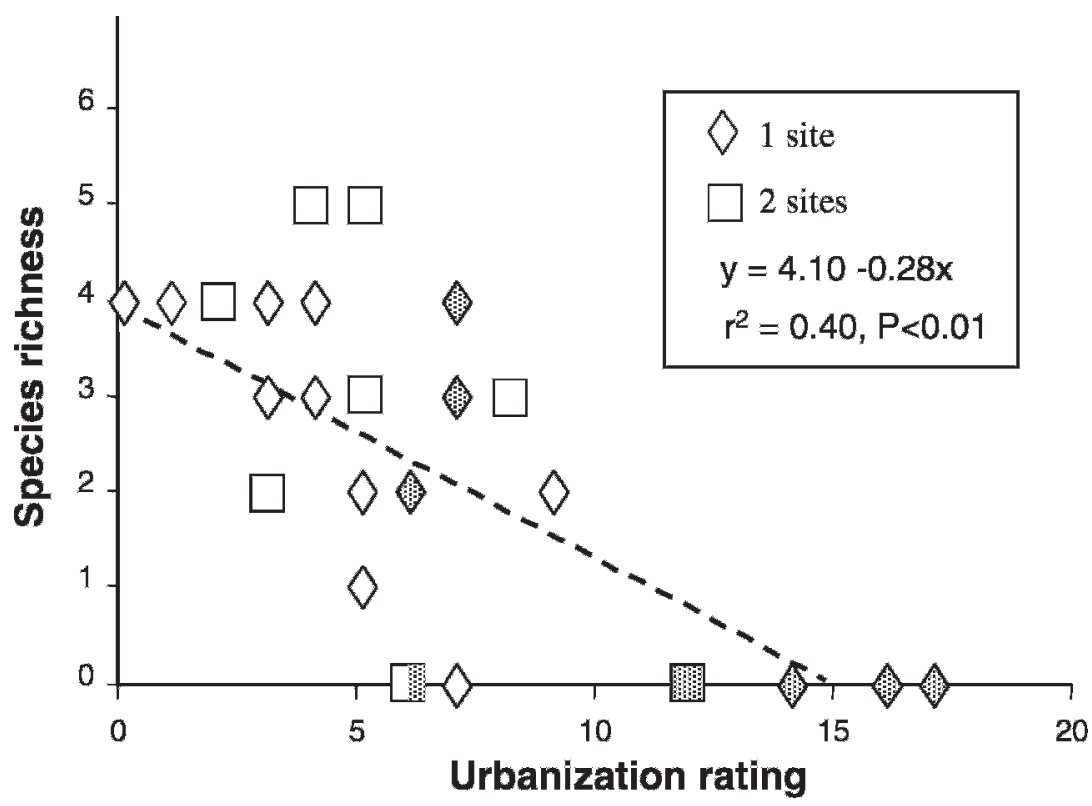

Fig. 3.-The relationship between urbanization score and species richness as indicated by the actual number of species observed living at a particular site and assuming that each site was an independent unit. Squares demarcate overlapping data points, and shading corresponds to sites within the urbanized regions of the watershed shown in Fig. 1

survey, A ligamentina, E dilatata and $P$ fasciolaris; which were identified in the main stem only from old shells, and Lampsilis cardium, for which few shells were found. Although biases in archeological data are possible based on shell size or thickness, the main stem of the Black River probably possesses a different unionid fauna today than it did 600 y ago. Change may arise partly from impacts even Native American agriculture can have on mussel communities (Peacock et al., 2005) and from the continued modification to the Lake Erie since Europeans first colonized the region (Conroy and Culver, 2004).

An early collection of shells by Robert L. Baird of Oberlin College describes the species present in Lorain County, Ohio; this county encompasses the city of Oberlin, through which Plum Creek runs (Fig. 1) and all of the Black River but the headwaters. While two other rivers flow through Lorain County, Baird explicitly listed the river on shells from these streams. In all, his collection included seven species that are now very rare in Ohio or are typical of old Lake Erie species (Table 5), and when found in neighboring streams, they are present only in the lower reaches if not the mouth near Lake Erie. Due to modern dredging of the Black River's mouth, our surveys identified no shells at the mouth. Combining information from all of these sources, the Black River harbored as many as 29 species of mussels once, with the majority of these restricted to the now urbanized main stem.

Dams are one more urbanization impact that changes mussel and fish distributions (Combes and Edds, 2005). Fish were more diverse below the first dam than upstream in the East and West Branch Black Rivers. The result does not support higher habitat quality there, because many fishes are transient migrants of Lake Erie populations (Trautmann, 1981). As noted already, the freshwater drum, Aplodinotus grunniens, is a critical species to mussel 
TABLE 4.-Presence of mussels and the number of potential known fish hosts present within the Black River system, Ohio

\begin{tabular}{|c|c|c|c|c|c|c|}
\hline Species & Main stem & Fish hosts & $\begin{array}{c}\text { East } \\
\text { Branch }\end{array}$ & Fish hosts & $\begin{array}{l}\text { West } \\
\text { Branch }\end{array}$ & $\begin{array}{l}\text { Fish }^{1} \\
\text { hosts }\end{array}$ \\
\hline Actinonaias ligamentina carinata & $\mathrm{S}$ & 11 & & 9 & & 5 \\
\hline Alasmidonta marginata & & 4 & $\mathrm{~S}$ & 2 & & 1 \\
\hline Alasmidonta viridis & & 2 & $\mathrm{~S}$ & 2 & & 2 \\
\hline Amblema plicata & $\mathrm{S}$ & 7 & & 5 & & 0 \\
\hline Anodontoides ferussacianus & & 8 & $\mathrm{~L}$ & 7 & $\mathrm{~L}$ & 5 \\
\hline Elliptio dilatata & $\mathrm{S}$ & 6 & & 1 & $\mathrm{~L}$ & 0 \\
\hline Fusconaia flava & & 4 & $\mathrm{~L}$ & 3 & & 1 \\
\hline Lampsilis cardium & $\mathrm{S}$ & 6 & & 5 & & 2 \\
\hline Lampsilis radiata luteola & $\mathrm{L}$ & 14 & $\mathrm{~L}$ & 9 & $\mathrm{~L}$ & 6 \\
\hline Lasmigona complanata & $\mathrm{L}$ & 5 & $\mathrm{~L}$ & 4 & $\mathrm{~L}$ & 2 \\
\hline Lasmigona compressa & $\mathrm{L}$ & 9 & $\mathrm{~L}$ & 6 & $\mathrm{~L}$ & 2 \\
\hline Lasmigona costata & $\mathrm{S}$ & 4 & & 3 & & 2 \\
\hline Leptodea fragilis & $\mathrm{L}$ & 1 & & 0 & & 0 \\
\hline Obovaria subrotunda & $\mathrm{S}$ & not known & & & & \\
\hline Potamilis alatus & $\mathrm{L}$ & 1 & & 0 & & 0 \\
\hline Ptychobranchus fasciolaris & $\mathrm{S}$ & not known & & & & \\
\hline Pyganodon grandis & $\mathrm{S}$ & 23 & $\mathrm{~L}$ & 16 & $\mathrm{~L}$ & 9 \\
\hline Strophitus undulatus & $\mathrm{S}$ & 19 & $\mathrm{~L}$ & 20 & $\mathrm{~L}$ & 7 \\
\hline Truncilla truncata & $\mathrm{S}$ & 1 & & 0 & & 0 \\
\hline Utterbackia imbecillis & $\mathrm{S}$ & 10 & & 6 & & 3 \\
\hline Villosa iris novi-eboraci & & 10 & $\mathrm{~L}$ & 8 & & 4 \\
\hline
\end{tabular}

\footnotetext{
${ }^{1}$ Fish survey of the West Branch Black River (Table 4) was limited in scope compared to the main stem and East Branch Black River
}

diversity in the region because it serves as the only known host for several species, Potamilus alatus, Leptodea fragilis and Truncilla truncata, and none of these species occurred above the first dam in the Black River or in neighboring rivers: Rocky River (Krebs and Rundo, 2005), Cuyahoga River (Smith et al., 2002; Tevesz et al., 2002) and the Grand River (Huehner et al., 2005). All other mussels found in this study had multiple hosts present, for example $L$. complanata infests the widely dispersed common carp (Cyprinus carpio) and green sunfish, Lepomis cyanellus (Lefevre and Curtis, 1910), and L. compressa and L. r. luteola infest bluegill (Lepomis macrochirus), smallmouth bass (Micropteris dolomieu) and several other common species (McGill et al., 2002; Watters, 1995). The only exception was Elliptio dilatata. This wide ranging species throughout Ohio (Watters, 1995) and northeast to Ontario's Grand River (Metcalfe Smith et al., 2000) lacked an identified host in the small West Branch Black River fish survey. That only a single white crappie, Pomoxis annularis and no E. dilatata were found in the East Branch Black River suggests that this species may be host limited in its distribution.

Similar changes to the unionid fauna are not present in comparisons of collections in the East Branch Black River and the West Branch Black River with the possible exception of Plum Creek, although little historical information is available for these streams. All nine mussel species recorded for the East Branch Black River and all seven for the West Branch Black River between 1950 and 1980 were identified in our survey, all were found alive or as fresh shells and most were abundant. Apparently little loss has occurred recently for the upstream habitat, which supports a July, 2005, decision by the United States EPA to upgrade the status of East Branch Black River from degraded to recovered (http://www.epa.state. 
TABLE 5.-Historical records of the unionid fauna of the Black River watershed. Ancient material derived from an archeological site along the main stem of the Black River, called White Fort (Tevesz et al., 2002). Results for the period around the turn of the 20th Century relate to voucher specimens collected by R. E Gall before 1900, and which became part of R. L. Baird's mollusk collection at Oberlin College, OH. Sampling after 1950 derives from records from the OSUMBD online database

\begin{tabular}{|c|c|c|c|c|c|}
\hline Species & $\begin{array}{l}\text { Present survey } \\
2005-2006\end{array}$ & $\begin{array}{c}\text { Ancient shells ca. } \\
1350\end{array}$ & $\begin{array}{l}\text { Surveys of } \\
1895-1904\end{array}$ & $\begin{array}{c}\text { Post } 1950 \text { East } \\
\text { Branch }\end{array}$ & $\begin{array}{c}\text { Post } 1950 \text { Wes } \\
\text { Branch }\end{array}$ \\
\hline Actinonaias ligamentina & $\mathrm{x}$ & 7 & $\mathrm{x}$ & & \\
\hline Alasmidonta marginata & $\mathrm{x}$ & & $\mathrm{x}$ & 2 & \\
\hline Alasmidonta viridis & $\mathrm{x}$ & & $\mathrm{x}$ & 8 & 1 \\
\hline Amblema plicata & $\mathrm{x}$ & 1 & $\mathrm{x}$ & & \\
\hline Anodontoides ferussacianus & $\mathrm{x}$ & & $\mathrm{x}$ & & 17 \\
\hline Elliptio complanata $^{1}$ & & & $\mathrm{x}$ & & \\
\hline Elliptio dilatata & $\mathrm{x}$ & 13 & $\mathrm{x}$ & & \\
\hline Epioblasma triquetra $^{1}$ & & & $\mathrm{x}$ & & \\
\hline Fusconaia flava & $\mathrm{x}$ & & $\mathrm{x}$ & 512 & \\
\hline Lampsilis cardium & $\mathrm{x}$ & 20 & $\mathrm{x}$ & & \\
\hline Lampsilis ovata ${ }^{1}$ & & & $\mathrm{x}$ & & \\
\hline Lampsilis radiata luteola & $\mathrm{x}$ & 1 & $\mathrm{x}$ & 68 & 67 \\
\hline Lasmigona complanata & $\mathrm{x}$ & & $\mathrm{x}$ & 59 & 2 \\
\hline Lasmigona compressa & $\mathrm{x}$ & & $\mathrm{x}$ & 7 & 7 \\
\hline Lasmigona costata & $\mathrm{x}$ & 1 & $\mathrm{x}$ & & \\
\hline Leptodea fragilis $^{3}$ & $\mathrm{x}$ & & & & \\
\hline Ligumia nasuta $^{1}$ & & & $\mathrm{x}$ & & \\
\hline Ligumia recta & & 2 & $\mathrm{x}$ & & \\
\hline Obovaria subrotunda & $\mathrm{x}$ & 3 & & & \\
\hline Pleurobema sintoxia ${ }^{1}$ & & & $\mathrm{x}$ & & \\
\hline Potamilus alatus & $\mathrm{x}$ & & $\mathrm{x}$ & & \\
\hline Ptychobranchus fasciolaris & $\mathrm{x}$ & 48 & $\mathrm{x}$ & & \\
\hline Pyganodon grandis & $\mathrm{x}$ & & $\mathrm{x}$ & 58 & 60 \\
\hline Quadrula quadrula ${ }^{2}$ & & & $\mathrm{x}$ & & \\
\hline Strophitus undulatus & $\mathrm{x}$ & & $\mathrm{x}$ & 16 & 4 \\
\hline Toxolasma parvus ${ }^{2}$ & & 1 & & & \\
\hline Truncilla truncata ${ }^{3}$ & $\mathrm{x}$ & & & & \\
\hline Utterbackia imbecillis & $\mathrm{x}$ & & $\mathrm{x}$ & & \\
\hline Villosa iris novi-eboraci & $\mathrm{x}$ & & $\mathrm{x}$ & 42 & \\
\hline Total specimens & & 97 & & 772 & 158 \\
\hline
\end{tabular}

${ }^{1}$ Rare species in Ohio today

${ }^{2}$ Species typical of lacustrine/estuarine environments

${ }^{3}$ New records for the river

oh.us/dsw/rap/BlackRivLetterFinal_Melster.pdf) based on surveys of the benthic macroinvertebrate community. This action was the first delisting of an impaired tributary of the Lake Erie watershed.

Each Lake Erie tributary contains a subset of the 44 species that have colonized the Lake Erie basin after the glaciers receded (Graf, 2002), but how many species should coexist in each stream is an open question. The neighboring Cuyahoga River has similarly suffered depletion of its molluscan fauna in its lower reaches (Smith et al., 2002), but not in the upper reaches or tributaries (Krebs et al., 2002; Tevesz et al., 2002), and Hoggarth (1990) describes the fauna of the Chagrin River as a remnant one. Just as Gillies et al. (2003) found 
in the Line Creek watershed near Atlanta, the presence of urbanization correlates with lower mussel diversity. Although no single aspect of urbanization can clearly be assigned as the cause for losing mussel species, Box and Mossa (1999) highlight the effects rapid water runoff that comes with more impervious surfaces. In a clean river, both richness and abundance of mussels should increase with watershed size as should the diversity of fish (Watters, 1992). The geographic association with Lake Erie may be the present source of more fish and the past source of more mussels. Until improvements occur, the Black River will remain largely isolated, and with few or no unionid mussel in Lake Erie (Bowers and de Szalay, 2004), the fate of the small main stem populations is tenuous.

Acknowledgments. - Our research was supported by a Research Experiences for Undergraduates (DBI 0243878) award from NSF to Mike Walton at CSU, and by small grants from Sea Grant (R/LR-9-PD) and an EFFRD award to RAK by Cleveland State University. We thank Tom Watters of the Ohio State University Museum of Biological Diversity for allowing us access to the collections of Robert L. Baird and Shimshon Balanson for assistance in the analysis of host fish relationships.

\section{Literature Cited}

Bauer, G. and K. Wachtler (eds.). 2001. Ecology and Evolution of the Freshwater Mussel Unionoida. Springer-Verlag Berlin, Germany.

Bowers, R. and F. A. DE Szalay. 2004. Effects of hydrology on unionids (Unionidae) and zebra mussels (Dreissenidae) in a Lake Erie coastal wetland. American Midland Naturalist, 151:286-300.

— J. J. Sudomir, M. W. Kershner and F. A. de Szalay. 2005. The effects of predation and unionid burrowing on bivalve communities in a Laurentian Great Lake coastal wetland. Hydrobiologia, 545:93-102.

Box, J. B. And J. Mossa. 1999. Sediment, land use, and freshwater mussels: prospects and problems. Journal of the North American Benthological Association, 18:99-117.

Combes, M. AND D. Edds. 2005. Mussel assemblages upstream from three Kansas reservoirs. Journal of Freshwater Ecology, 20:139-148.

Conroy, J. D. and D. A. Culver. 2004. Do dreissenid mussels affect Lake Erie ecosystem stability processes? American Midland Naturalist, 153:20-32.

Dillon, R. T. 2000. The Ecology of Freshwater Mollusks. Cambridge University Press, New York.

Gillies, R. R., J. B. Box, J. Symanzik and E. J. Rodemaker. 2003. Effects of urbanization on the aquatic fauna of the Line Creek watershed, Atlanta - a satellite perspective. Remote Sensing of Environmant, 86:411-422.

GRAF, D. L. 2002. Historical biogeography and late glacial origin of the freshwater pearly mussel (Bivalvia: Unionidae) faunas of Lake Erie, North America. Museum of Comparative Zoology, Occasional Papers on Mollusks, 6:175-210.

HAAG, W. R. AND M. L. WARREN. 2000. Effects of light and presence of fish on lure display and larval release behaviours in two species of freshwater mussels. Animal Behaviour, 60:879-886.

Hardison, B. S. AND J. B. LaYzer. 2001. Relations between complex hydraulics and the localized distribution of mussels in three regulated rivers. Regulated Rivers - Research $\mathcal{E}$ Management, 17:77-84.

Hoggarth, M. 1990. The Unionidae of the Chagrin River: the remnant of a molluscan fauna. Ohio Journal of Science, 90:168-170.

Howard, A. D. 1913. The catfish as a host for fresh-water mussels. Transactions of the American Fisheries Society, 42:65-70.

Huehner, M. K., R. A. Krebs, G. Zimmerman and M. Mejia. 2005. The unionid mussel fauna of northeastern Ohio's Grand River. Ohio Journal of Science, 105:57-62.

Hughes, M. H. and P. W. Parmalee. 1999. Prehistoric and modern freshwater mussel (Mollusca: Bivalvia: Unionidae) faunas of the Tennessee River: Alabama, Kentucky, and Tennessee. Regulated Rivers - Research E्O Management, 15:25-42. 
JAMEs, M. R. 1987. Ecology of the freshwater mussel Hyridella menziesi (Gray) in a small oligotrophic lake. Archiv Fur Hydrobiologie, 108:337-348.

Krebs, R. A., H. M. Griffith and M. J. S. Tevesz. 2002. A study of the Unionidae of Tinkers Creek, Ohio. Kirtlandia, 53:19-25.

AND L. J. Rundo. 2005. Diversity of the Unionidae in the Rocky River, Ohio. Journal of Freshwater Ecology, 20:603-608.

Lawler, J. J., D. White, J. C. Sifneos and L. L. Master. 2003. Rare species and the use of indicator groups for conservation planning. Conservation Biology, 17:875-882.

Lefevre, G. and W. C. CuRTis. 1910. Reproduction and parasitism in the Unionidae. Journal of Experimental Zoology, 9:79-115.

Mackie, G. L. 1984. Bivalves, p. 351-418. In: N. H. Tonpa, J. A. M. Verdonk, A. S. van den Biggelaar and K. M. Wilbuer (eds.). The Mollusca vol 7. Reproduction. Academic Press, London.

McClelland, M. A., M. A. Pegg and T. W. Spier. 2006. Longitudinal patterns of the Illinois waterway fish community. Journal of Freshwater Ecology, 21:91-99.

McGill, M., M. Hove, T. Diedrich, C. Nelson, W. Taylor and A. Kapuscinski. 2002. Several fishes are suitable hosts for creek heelspiltter glochidia. Ellipsaria, 4:18-19.

Metcalfe-Smith, J. L. and J. Di Maio. 2000. Effect of sampling effort on the efficiency of the timed search method for sampling freshwater mussel communities. Journal of the North American Benthological Association, 19:725-732.

G. L. Mackie, J. Di Maio and S. K. Staton. 2000. Changes over time in the diversity and distribution of freshwater mussels (Unionidae) in the Grand River, southwestern Ontario. Journal of Great Lakes Research, 26:445-459.

—, S. K. Staton, G. L. Mackie and N. M. Lane. 1998. Changes in the biodiversity of freshwater mussels in the Canadian waters of the lower Great Lakes drainage basin over the past $140 \mathrm{y}$. Journal of Great Lakes Research, 24:845-858.

Онго EPA. 1989. Biological Criteria for the Protection of Aquatic Life, Volume III: Standardized Biological Field Sampling Methods for Assessing Fish and Macroinvertebrate Communities. State of Ohio Environmental Protection Agency, Division of Water Quality, Environmental Assessment Section, Columbus, Ohio.

1999. Biological and Water Quality Study of the Black River Basin, Lorain and Medina Counties. Division of Water Quality, Ecological Assessment Section, Columbus, Ohio. OEPA Technical Report Number MAS/1998-11-4 (accessed at www.epa.state.oh.us/dsw/documents/black97.pdf)

Peacock, E., W. R. Haag and M. L. Warren, Jr. 2005. Prehistoric decline in freshwater mussels coincident with the rise of maize agriculture. Conservation Biology, 19:547-551.

Seshaiya, R. V. 1969. Some observations on the life histories of South Indian freshwater mussels. Malacologia, 9:286-287.

Smith, D. C., M. A. Gates, R. A. Krebs and M. J. S. Tevesz. 2002. A survey of the freshwater mussels (Unionidae) and other molluscs in the Cuyahoga Valley National Park. Ohio Biological Survey Miscellaneous Contributions. No. 8.31 p.

Strayer, D. L., D. C. Hunter, L. C. Smith and C. K. Borg. 1994. Distribution, abundance, and roles of fresh-water clams (Bivalvia, Unionidae) in the fresh-water tidal Hudson River. Freshwater Biology, 31:239-248.

Tevesz, M. J. S., L. J. Rundo, R. A. Krebs, B. G. Redman and A. S. Dufresne. 2002. Changes in the freshwater mussel (Bivalvia: Unionidae) fauna of the Cuyahoga River, Ohio, since late prehistory. Kirtlandia, 53:13-18.

Trautman, M. B. 1981. The Fishes of Ohio. Ohio State University Press, Columbus, Ohio.

Vaughn, C. C. 1997. Regional patterns of mussel species distributions in North American rivers. Ecography, 20:107-115.

AND C. C. HakenKamp. 2001. The functional role of burrowing bivalves in freshwater ecosystems. Freshwater Ecology, 46:1431-1446.

AND C. M. TAYLoR. 2000. Macroecology of a host-parasite relationship. Ecography, 23:11-20.

Watters, G. T. 1992. Unionids, fishes, and the species area curve. Journal of Biogeography, 19:481-490. 
1995. A Guide to the Freshwater Mussels of Ohio, 3rd ed. Ohio Division of Wildlife, Department of Natural Resources, Columbus, Ohio. 122 p.

1996. Small dams as barriers to freshwater mussels (Bivalvia, Unionidae) and their hosts. Biological Conservation, 75:79-85.

Post-print standardized by MSL Academic Endeavors, the imprint of the Michael Schwartz Library at Cleveland State University, 2015 